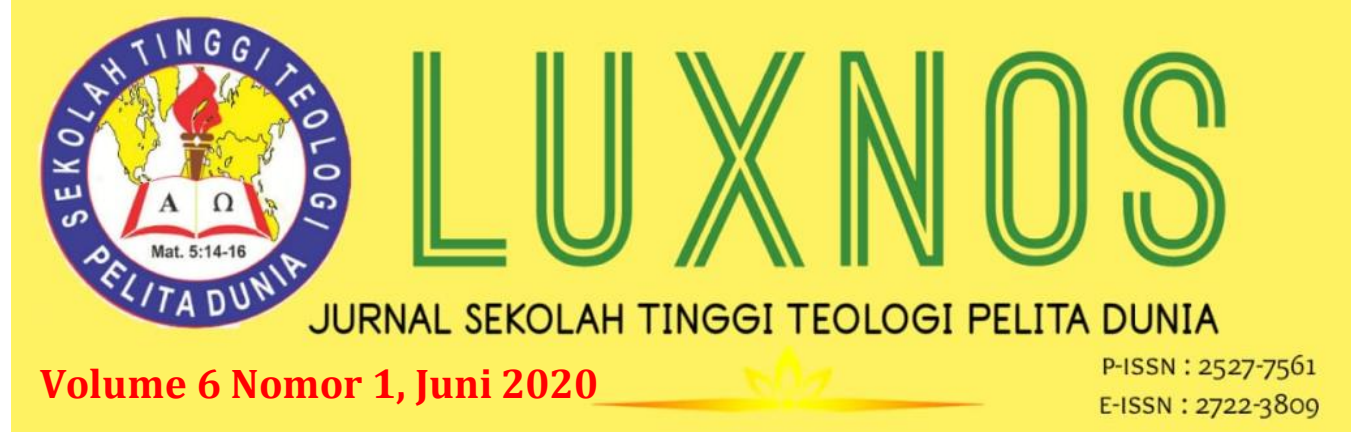

\title{
Buah Roh Dalam Galatia 5:22-23 \\ Dan Penerapannya Bagi Pendidikan Agama Kristen
}

\author{
Yosia Belo, Sekolah Tinggi Teologi Injili Arastamar Jakarta, \\ ociebelo42@gmail.com
}

\begin{abstract}
This research is a literature study of the fruits of the Spirit in Galatians 5: 22-23. By using a qualitative approach, the results [Grab your reader's attention with a great quote from the document or use this space to emphasize a key point. To place this text box anywhere on the page, just drag it.] are found that the fruits of the Spirit should be owned by every student who has studied Christian Religious Education. Therefore it is a sign of the presence of the Holy Spirit in each of their lives and at the same time shows the change or transformation brought about by the Bible study they learned in the Christian Religious Education class.

Keywords: Spirit Fruit, Galatians, Christian Religious Education
\end{abstract}

\begin{abstract}
Abstraksi: Penelitian ini merupakan penelitian pustaka terhadap buahbuah Roh dalam Galatia 5:22-23. Dengan menggunakan pendekatan kualitatif, maka ditemukan hasil bahwa buah-buah Roh sudah seharusnya dimiliki oleh setiap peserta didik yang telah belajar Pendidikan Agama Kristen. Oleh karena itu sebagai tanda kehadiran Roh Kudus dalam setiap kehidupan mereka dan sekaligus menunjukkan perubahan atau transformasi yang ditimbulkan oleh pelajaran Alkitab yang mereka pelajari dalam kelas Pendidikan Agama Kristen.
\end{abstract}

Kata Kunci: Buah Roh, Galatia, Pendidikan Agama Kristen

\section{Pendahuluan}

Pendidikan Agama Kristen (PAK) adalah pendidikan yang menuntut terjadinya perubahan dan transformasi dalam kehidupan peserta didik. Hal ini sangat dimungkinkan karena PAK didasarkan pada Alkitab sebagai sumber utama dan dasar filosofis kurikulumnya. Seperti yang dipelajari dalam teologi Kristen, bahwa setiap orang yang meneliti dan mempelajari Alkitab akan senantiasa dipimpin dan dicerahkan oleh Roh Kudus. Mereka dapat memahami setiap apa yang mereka baca dan pelajari. Tidak 


\section{JURNAL LUXNOS \\ Volume 6 Nomor 1, Juni 2020}

hanya mengerti namun juga dapat mengubah kehidupan mereka melalui tindakan praktis yang senantiasa mereka lakukan berdasarkan ajaran Alkitab.

Perubahan yang terjadi dalam buah Roh yang ditunjukkan oleh setiap peserta didik. Dalam Galatia 5, sebelum Paulus menjelaskan tentang buah Roh, terlebih dahulu dia mengemukakan tentang perbuatan daging. Seolah-olah hendak menegaskan bahwa setiap orang Kristen harusnya meninggalkan perbuatan daging dan selanjutnya hidup menghasilkan buah-buah Roh. Dengan menyandingkan dalam satu perikop antara perbuatan daging dengan buah Roh, maka Paulus hendak mempertentangan keduanya.

Dengan demikian, penting sekali untuk memahami seperti apa sebenarnya maksud buah Roh dalam konteks Galatia 5 dan bagaimana menerapkannya dalam konteks PAK.

\section{Metode Penelitian}

Pada penelitian ini menggunakan metode kualitatif, di mana lebih menitikberatkan pada kajian pustaka guna memperoleh hasil penelitian yang memadai perihal makna atau maksud buah Roh dalam Galatia 5:22-23.

\section{Hasil dan Pembahasan}

Pada Galatia 5:22-23, Paulus menjelaskan atau memberikan daftar buah Roh. Buah Roh ini berupa nilai-nilai hidup yang bertolak belakang dengan perbuatan daging (ay. 1921). Sebelum membicarakan lebih jauh membicarakan lebih jauh dan dalam tentang topik ini, maka perlu untuk memperhatikan tiga hal penting berikut ini.

Hal penting yang pertama, apabila berbicara tentang perbuatan daging atau keinginan manusia, maka Rasul Paulus memakai istilah pekerjaan. Sedangkan apabila berbicara mengenai Roh Allah, maka Paulus menggunakan istilah buah Roh. Hal ini penting untuk diketahui dan dipahami, oleh karena perbuatan daging berasal dari usaha manusia. Perbuatan daging dapat dikatakan sama dengan melakukan Hukum Taurat. Di pihak yang lain, buah Roh merupakan kebaikan yang dilakukan oleh orang Kristen karena hubungannya dengan Roh Allah, dan hal ini terlihat wajar dalam setiap perbuatan dan tingkah laku orang Kristen. Bandingkan dengan pendapat McKnight,

Paul describes "flesh" under the term works, while he sees the Spirit's work as "fruit." The former is plural while the latter is singular. Is there anything significant in the change of terms or the change of number? Above all, it must be observed that works has been a term of negative associations in Galatians and that Paul probably delighted in associating the "works" of the flesh with the "works of the law" $(2: 16 ; 3: 2,5,10)$. The change of terms to "fruit" evokes a different image: from one of human responsibility to one of divine enablement. The image of fruit 


\section{JURNAL LUXNOS \\ Volume 6 Nomor 1, Juni 2020}

has a certain sense of passivity to it; it is the Spirit of God who produces such things, and they grow in the life of the Christian.1

Kedua, yang juga perlu untuk diperhatikan adalah "buah Roh" merupakan kata benda dan dalam bentuk tunggal. Hal ini memberikan semacam indikasi bahwa Paulus hendak menekankan tentang kehidupan rohani yang merupakan sebuah kesatuan, sehingga semua kebaikan yang terdapat dalam daftar buah Roh itu pasti dapat ditemukan pada setiap orang yang hidupnya dipimpin oleh Roh Allah.

Ketiga, Paulus juga berbicara tentang "karunia-karunia Roh" (1Kor. 12:1-11). Perlu diketahui bersama bahwa itu tidak sama dengan buah Roh dalam bagian ini. Berbicara karunia-karunia Roh, maka itu berbicara tentang tugas atau kemampuan yang diberikan kepada orang-orang Kristen supaya dapat melayani dengan baik. Jelas, bahwa karunia yang diterima masing-masing orang, berbeda satu sama lainnya. Sebaliknya, buah Roh dimiliki seluruhnya oleh setiap orang yang dipimpin oleh Roh Allah.

Berdasarkan pemaparan Paulus dalam bagian ini, bahwa ada sembilan buah Roh. Di mana masing-masingnya memiliki sifat yang selalu bertentangan dengan manusia yang masih dikuasai oleh kedagingan dan hawa nafsu. Setiap buah Roh ini dipraktikkan dalam relasinya dengan orang Kristen dan juga sesama manusia.

Ungkapan "kasih" merupakan lawan dari "perseteruan" (ay. 20). Menurut J.R.W. Stott, "While "love" is not the only "fruit" of the Spirit, it is the most important to Paul (cf. vv. 6, 13-14; also Rom. 5:5; 1 Cor. 13; Col. 3:14)".2 Ditambahkan oleh McKnight, It summarizes the demand of God's law (Galatia 5:14), endures forever (1 Cor 13:13), and unites all the virtues of life (Col. 3:14). Fundamental to Paul's view, however, is that love comes from God's Spirit ( $c f$. Rom. 5:5). Moreover, as we look over this list, we observe the reverse of the list of the works of the flesh. Whereas the flesh destroys fellowship; here the Spirit creates fellowship, unity, and holiness. 3

Oleh karena itu di sini tidak berarti kasih terhadap Allah, melainkan kasih terhadap sesama. Bahkan bagian ini dapat juga diterjemahkan dengan cara mengubahnya seolaholah menjadi verba, mereka saling mengasihi. Ternyata dalam kata "kasih" ada tersirat bahwa ada yang mengasihi dan ada yang dikasihi.

Kata "sukacita", yang meskipun seringkali terlepas dari keadaan luar yang dihadapi oleh seseorang, karena dasar sukacita itu adalah Allah sendiri. Supaya sukacita tidak diartikan hanya sekadar pengalaman sementara saja, maka kata tersebut dapat juga diterjemahakn menjadi sungguh-sungguh gembira dari lubuk hati. Namun yang perlu

${ }^{1}$ Scot McKnight, The NIV Application Commentary: Galatians, (Grand Rapids, Michigan: Zondervan, 1995), hlm. 271.

2 J. R. W. Stott, The Contemporary Christian (USA: I V P, 1992).

${ }^{3}$ McKnight, hlm. 271. 


\section{JURNAL LUXNOS \\ Volume 6 Nomor 1, Juni 2020}

digarisbawahi di sini adalah bahwa sukacita yang ditunjukkan merupakan sukacita atau rasa gembira yang bersumber pada Allah. Balz-Schneider mengatakan,

"If "Spirit" constitutes God's most characteristic presence in the world, then joy is to a large extent the result of God's presence among human beings. The Spirit generates joy, along with righteousness and peace, as its fruit (Gal 5:22; Rom 14:17). It enables a person to endure joyfully the suffering and trials of Christian existence (1 Thess 1:6). Being filled with joy and the Spirit is itself a sign of the legitimacy of the mission to the Gentiles (Acts 13:52 after 13:47f., 50f.). Cf. also Luke 10:21 (exultation in the Holy Spirit over the criteria for election) and the inspiration of joy according to Philo (Som. ii.249; Abr. 201). Hence joy in this world is viewed as a witness to the activity of God himself. Cf. also 1 Clem. 63:2;

HeRoma Vis. iii.13.2 (renewal of the pneuma through joy)".4

Ungkapan "damai sejahtera" terdiri dari dua kata dalam terjemahan bahasa Indonesia - namun dalam teks Yunaninya menggunakan satu kata saja. Hal ini mengindikasikan bahwa ungkapan Yunani yang digunakan bagi "damai sejahtera" memiliki makna yang luas, di mana mencakup keduanya yakni: damai dan sejahtera. Dalam bahasa Yunani, kata "damai" mempunyai makna tanpa kekuatiran dan kegelisahan, disebabkan hubungan yang baik dengan Allah ataupun dengan sesamanya, karena iman kepada Yesus Kristus. Balz-Schneider menegaskan, "The new relationship of peace with God brings the Church toward its full development. Peace effects the sanctification on the day of the parousia (1 Thess 5:23). When liberated from legal prescriptions, the righteousness and joy of God's kingdom are viewed as the result (Rom 8:6) and the fruit of the Holy Spirit (Gal 5:22; Rom 2:10; 14:17). The Spirit's structure of peace gives form to life in the Church. Thus Paul's exhortations aim in this direction: One is to pursue peace (Rom 14:19), keep peace with one another (1 Thess 5:13; 2 Cor 13:11; Rom 12:18), and make peace the watchman over heart and mind (Phil 4:7). Ethical (1 Cor 5), legal (6:1ff.), and marital relationships (7:12ff.) are to fall under the sway of peace. Peace is to be determinative in communal worship (14:33) and in communication between the apostle and his coworkers (16:11)".5

Dengan demikian, kata "damai" lebih cenderung menegaskan "damai dengan sesama manusia". Sehingga opsi lain bagi terjemahannya dapat juga dibuat dengan hidup damai dengan sesama atau hidup dengan orang lain tanpa ada pertengkaran.

Kesabaran merupakan sifat yang menunjukkan kepada kemampuan untuk menahan diri untuk tidak marah atau melakukan tindakan pembalasan walau ada

\footnotetext{
${ }^{4}$ Horst Balz \& Gerhard Scheider, Exegetical Dictionary of The New Testament (EDNT) (Michigan: Grand Rapids, 1990).

5 Ibid.
} 


\section{JURNAL LUXNOS \\ Volume 6 Nomor 1, Juni 2020}

provokasi atau pancingan dari orang lain. Kata ini dapat juga diterjemahkan menjadi tahan menderita atau tetap tenang walaupun diancam.

Kemurahan dan kebaikan merupakan sifat atau kebiasaan yang baik yang ditujukan terhadap sesama. Kemurahan berarti suka menolong dan berbuat baik kepada orang lain. Sehingga kata ini juga tidak salah apabila diterjemahkan suka menolong. Sedangkan kebaikan dapat juga diterjemahkan suka berbuat baik kepada orang lain.

Kata "kesetiaan" seringkali diterjemahkan dengan "percaya" atau "iman". Kata ini menggambarkan hubungan manusia dengan Allah. Namun dalam konteks ini yang ditekankan oleh Paulus adalah seseorang yang setia, dapat dipercaya, jujur, dan dapat diandalkan dalam hubungannya dengan orang lain. Jadi dapat diterjemahkan menjadi dapat dipercayai, diandalkan dan jujur. Menurut Balz-Schneider,

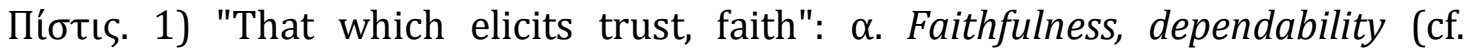

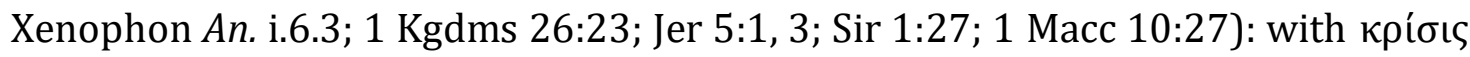

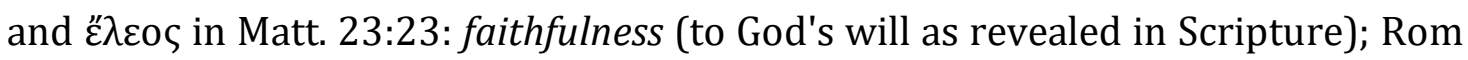

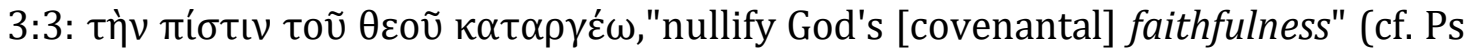

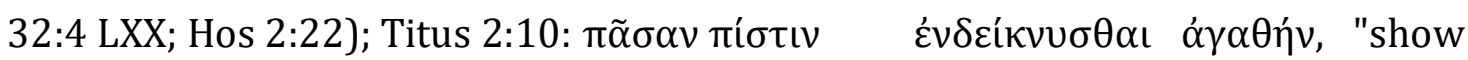
entire and true fidelity." With other virtues in Gal 5:22; 2 Tim 4:7: "I have kept

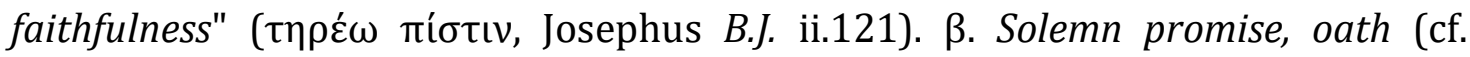
Xenophon Cyr. vii.1.44; Plato Lg. iii.701c; 3 Macc 3:10; Josephus Ant. xii.382): 1 Tim

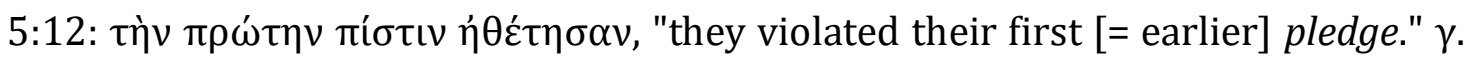
Proof (cf. Plato Phd. 70b; Epictetus Diss. i.28.3; Josephus Ant. xv.69): Acts 17:31:

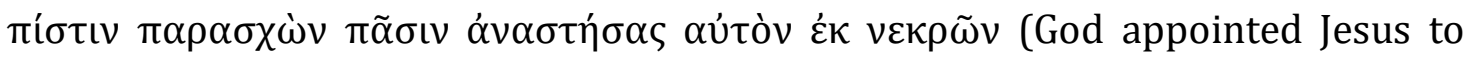
judge the world), "he has given proof [of his choice of Jesus] to all by raising him from the dead."6

Kelemahlembutan berarti sabar dan lemah lembut terhadap orang lain. Dalam bentuk negatif dapat dikatakan tidak kasar kepada orang lain atau tidak memaksakan kehendak kepada orang lain. Selanjutnya penguasaan diri yang merupakan daftar buah Roh yang terakhir. Ungkapan ini sendiri dapat dipahami dengan sebuah kemampuan untuk menguasai keinginan diri sendiri. Dalam konteks ini penguasaan diri ini lebih cocok dengan arti yang lebih umum daripada hanya penguasaan diri terhadap hawa nafsu.

Bagian ini ditutup oleh Paulus dengan mengatakan, "tidak ada hukum yang menentang hal-hal itu". Menurut Balz-Schneider,

Paul makes his fundamental theological statement that justification comes not through works of the law but through faith alone in Romans as well as Galatians (Rom $3: 20-22,28)$. Only when one considers that he does so does the importance of the

${ }^{6}$ Ibid. 


\section{JURNAL LUXNOS \\ Volume 6 Nomor 1, Juni 2020}

(now, in Romans, altered) vó Galatians and Romans is the teaching of justification; the variable is the concept of the law. In Romans we find statements that would have been impossible in the flow of the argument in Galatians: the law is holy, its commandment is holy, righteous, and

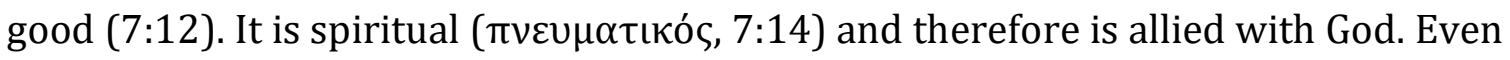
circumcision is no longer viewed as purely negative (2:25-27; 3:1f.; 4:10-12). There is no longer mention of the law being given through an angel or its being intended to provoke evil deeds; the function of the law is now to make sin conscious (3:20; 7:7).

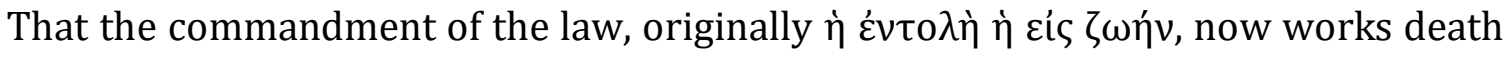
(7:10), is only the fault of the power of sin. The argument regarding the "whole law" is also lacking; in 13:8-10 love is the fulfillment of the (now, finally) Mosaic law; every commandment is fulfilled in the love command. 7

Di sini, yang Paulus maksudkan adalah hukum Taurat yang tidak memiliki peran apa-apa dalam kehidupan rohani. Dapat kita mengerti dan pahami bahwa Hukum Taurat berguna untuk menghalangi seseorang agar tidak melakukan hal-hal yang tidak baik, sedangkan dalam "buah Roh", yang disebutkan tadi tidak ada satu pun yang tidak baik, dan karena itu tidak perlu dihalangi. Karena memang tidak ada hukum yang mengatur hal-hal seperti ini.

\section{Penerapannya Bagi Pendidikan Agama Kristen}

Setelah melakukan penelitian pustaka di atas yang menitikberatkan pada data atau informasi dari tafsiran Galatia 5:22-23, maka berikut ini akan diuraikan hasil dan penerapannya bagi Pendidikan Agama Kristen.

Kasih dalam konteks ini berarti kasih kepada sesama manusia sebagai implementasi kasih Kristus yang telah dimiliki oleh setiap orang percaya. Dengan demikian, setiap peserta didik yang telah belajar PAK sudah seharusnya memiliki kasih yang nyata bagi sesamanya.

Sukacita yang dimaksud adalah sukacita yang dimiliki oleh orang percaya atau peserta didik karena kehadiran Kristus dalam setiap kehidupan mereka. Demikian itu terpancar untuk selama-lamanya.

Damai sejahtera cenderung menegaskan "damai dengan sesama manusia". Sehingga opsi lain bagi terjemahannya dapat juga dibuat dengan hidup damai dengan sesama atau hidup dengan orang lain tanpa ada pertengkaran.

Kesabaran menunjukkan kepada kemampuan untuk menahan diri untuk tidak marah atau melakukan tindakan pembalasan walau ada provokasi atau pancingan dari

\footnotetext{
7 Ibid.
} 
orang lain. Kata ini dapat juga diterjemahkan menjadi tahan menderita atau tetap tenang walaupun diancam.

Kemurahan dan kebaikan merupakan sifat atau kebiasaan yang baik yang ditujukan terhadap sesama. Kemurahan berarti suka menolong dan berbuat baik kepada orang lain. Sehingga kata ini juga tidak salah apabila diterjemahkan suka menolong. Sedangkan kebaikan dapat juga diterjemahkan suka berbuat baik kepada orang lain.

Kesetiaan merujuk kepada seseorang yang setia, dapat dipercaya, jujur, dan dapat diandalkan dalam hubungannya dengan orang lain. Jadi dapat diterjemahkan menjadi dapat dipercayai, diandalkan dan jujur.

Kelemahlembutan berarti sabar dan lemah lembut terhadap orang lain. Dalam bentuk negatif dapat dikatakan tidak kasar kepada orang lain atau tidak memaksakan kehendak kepada orang lain.

Penguasaan diri dapat dipahami dengan sebuah kemampuan untuk menguasai keinginan diri sendiri. Dalam konteks ini penguasaan diri ini lebih cocok dengan arti yang lebih umum daripada hanya penguasaan diri terhadap hawa nafsu.

Dengan demikian, setiap peserta didik yang telah belajar PAK yang mana didasarkan pada filosofi Alkitab maka seharusnya memberikan perubahan dan transformasi yang radikal dalam setiap kehidupan mereka seperti yang tampak dalam buah-buah Roh.

\section{Kesimpulan}

Setelah melalui proses penelitian pustaka maka dapat disimpulkan bahwa buahbuah Roh dalam Galatia 5:22-23 seharusnya tampak dalam kehidupan peserta didik sebagai bentuk kehadiran Roh Kudus dan perubahan yang ditimbulkan setelah belajar Alkitab dalam kelas Pendidikan Agama Kristen.

\section{Referensi}

Scot McKnight, The NIV Application Commentary: Galatians, Grand Rapids, Michigan: Zondervan, 1995.

J. R. W. Stott, The Contemporary Christian (USA: I V P, 1992.

Horst Balz \& Gerhard Scheider, Exegetical Dictionary of The New Testament (EDNT)

(Michigan: Grand Rapids, 1990.

G.J. Wenham. D.A. Carson, R.T. France, J.A. Motyer, ed., Tafsiran Alkitab Abad Ke-21

(Matius-Wahyu) (Jakarta: YKBK/OMF, 2017. 